\title{
O ENTREMEIO DAS PINTURAS VIVAS: TRADUÇÃO INTERSEMIÓTICA E COAUTORIA NOS INTERTEXTOS DE BILL VIOLA
}

THE INTERLUDE OF LIVING PAINTINGS: INTERSEMIOTIC TRANSLATION

AND COAUTHORING IN THE INTERTEXTS OF BILL VIOLA

Filipe Rafael Vebber

PPGAV-Unicamp

Resumo: $O$ objetivo deste artigo é refletir sobre o processo de criação do videasta Bill Viola, marcado pela intertextualidade e pelo exercício de recodificação denominada tradução intersemiótica. As relações geradas nesse processo implicam na discussão de aspectos éticos do conceito de autoria. Além de atestar sua natureza sensorial e provocativa, espera-se realçar o caráter interdisciplinar do modo como a produção de imagens se atualiza conforme a tecnologia disponível em seu tempo presente.

Palavras-chave: Bill Viola, Intertextualidade, Tradução Intersemiótica.

Abstract: this article intends to reflect on the creation process of the video artist Bill Viola, marked by intertextuality and by the exercise of recoding designated as intersemiotic translation. The connections generated in this process implies the discussion of ethical aspects of the concept of authorship. In addition to attesting to its sensory and provocative nature, it is expected to highlight the interdisciplinary character of how the production of images is updated according to a technology available in its present time.

keywords: Bill Vola, Intertextuality, Intersemiotic Translation. 


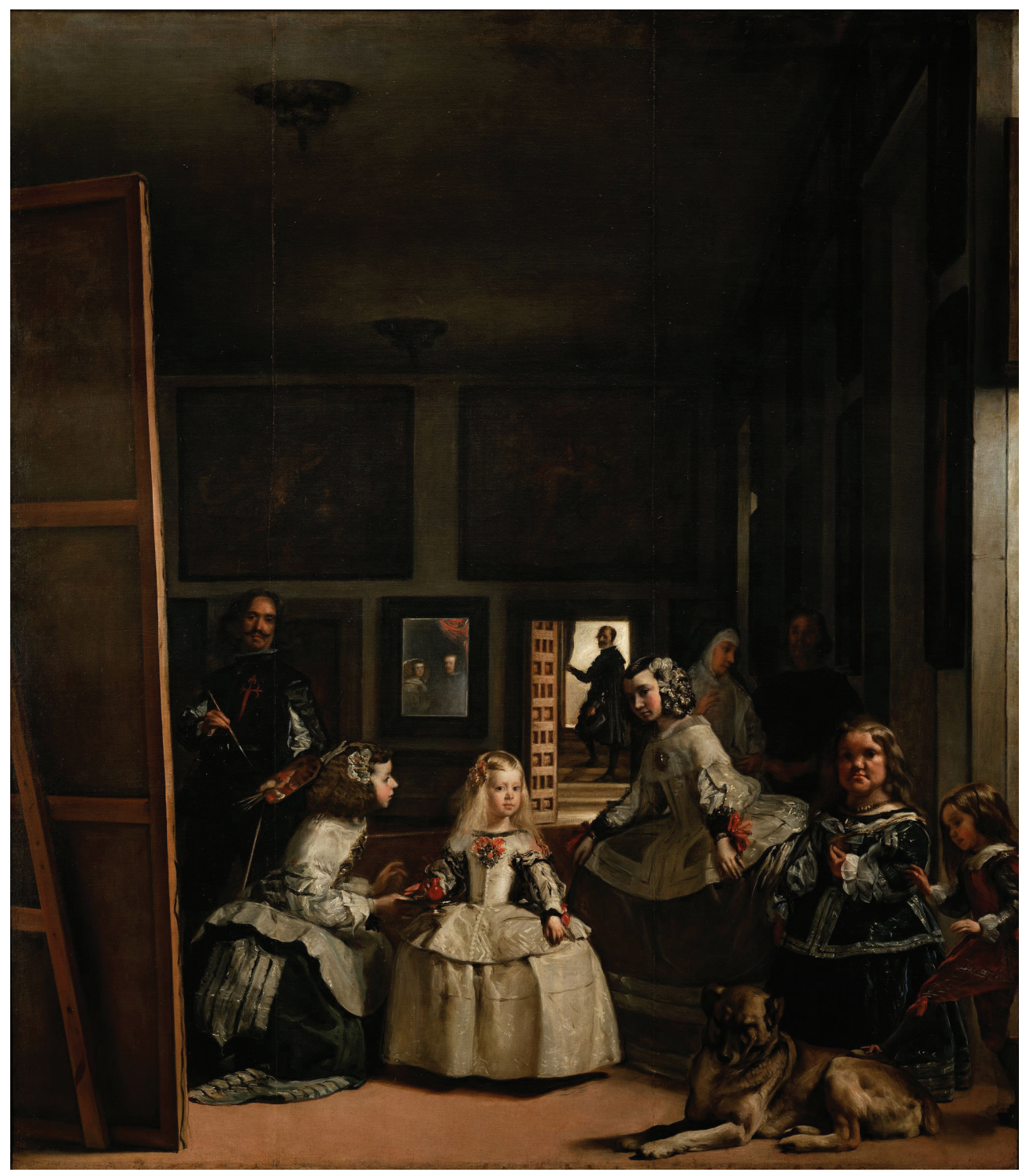

\section{Preâmbulo sobre o conceito de autoria: de que importa quem fala?}

"Artistas bons copiam, grandes artistas roubam". Essa frase, largamente citada como de autoria do pintor espanhol Pablo Picasso, gera grande debate ainda hoje. Essa mensagem não só parece defender a ideia da cópia ou da apropriação de imagens, como também explicaria motivações gerativas das pinturas de Picasso realizadas como estudos das obras de Manet, Toulouse-Lautrec, Ingres e Velázquez, entre outros. De imediato, tais considerações geram certos questionamentos: é adequado para um artista copiar/roubar ideias de outro para produzir suas obras? Quais implicações tem-se a partir dessa postura quanto à ética e à poética 
na arte? E como essas implicações afetam as relações entre autoria e propriedade intelectual no contexto atual?

Vejamos como se dá essa problemática. Embora seja verdade que artistas contemporâneos utilizam da intertextualidade em seus processos criativos numa frequência como nunca antes vista, a apropriação de imagens no mundo da arte existe há muito tempo. 0 enfoque prestado a esse trabalho está em lançar um olhar meticuloso sobre o processo da intertextualidade como alternativa conceitual na arte. Assim, convida-se a refletir sobre o processo de tradução do objeto artístico, ao passo em que se analisa as provocações geradas por esse deslocamento textual entre enunciados.

No Ocidente, a estima pela obra de arte original está intimamente ligada à instituição dos museus no final do século XVIII e, nos EUA, no século XIX, onde os espectadores do público em geral puderam ver obras originais de arte ao vivo, pela primeira vez. É sabido que, antes da edificação dos espaços expositivos, apenas uma seleta elite tinha acesso às obras de arte, quando não apenas os donos delas. Pinturas como Las Meninas, de Velazquez (Figura 3), encomendadas pela nobreza diretamente ao retratista, permaneciam reservadas aos olhos do público até que esses espaços foram instituídos. Não obstante, grande parte dos parâmetros constituintes da ideologia moderna estavam cimentados nesse aspecto aurático da originalidade da obra.

A arte contemporânea coloca em perspectiva o projeto moderno hegemônico construído histórica e socialmente associados ao fazer do artista/autor. Com efeito, são surpreendentes as transformações processadas nas práticas artísticas da atualidade, tanto na ordem geracional quanto na ordem de consumo dos artefatos. Em contrapartida, jamais se viu tamanho enga- jamento das esferas populares no que tange à procura e disseminação da arte, principalmente em razão da internet. De fato, a quebra com o paradigma estético e também com as tradições que antes legitimavam as manifestações criativas, marginalizaram as configurações ditas puristas e inflexíveis dos critérios modernos.

Foi a impossibilidade de manutenção dessa agenda reducionista que fez sucumbir o projeto moderno (Hinkel, 2016). Consequentemente, o estatuto da arte passou a rejeitar instituições, métodos e termos que antes validavam o que se entendia como práticas ou produtos artísticos.

\section{O autor: ser absoluto, dono de tudo}

É nesse contexto que surge a figura do autor como proprietário absoluto da obra (Barthes, 2004). O prestígio dessa personagem gerava um desejo incisivo em ser celebradoㄹ, e a partir daí construiu-se uma instituição acerca da propriedade intelectual que gera fervoroso debate até hoje.

Entretanto, não tardou para que se criticasse a concepção normalizada de autoria como posse e tratou-se de contestá-la por meio de teorias que despontavam ao redor do globo sobre a (im)possibilidade do ser unívoco e completo em si mesmo. Tal confronto teve início, como se sabe, nos estudos discursivos bakhtinianos, nos quais o autor (Bakhtin, 2003) apontou o diálogo ininterrupto do sujeito com pensamentos externos e atingiu seu ápice com a publicação do ensaio de Roland Barthes intitulado "A morte do autor", em 1967. Sabe-se, com isso,

que um texto não é feito de uma linha de palavras, libertando um sentido único, de certo modo teológico (que seria a «mensagem» do Autor-Deus), mas um espaço de dimensões

1 Antes da modernidade, os autores eram bem menos aclamados. Muitos são os exemplos de artistas cujos proventos sucintos faziam-los levar uma existência humilde e sem toda a espetacularização conhecida a partir dos moldes modernos. 
múltiplas, onde se casam e se contestam escritas variadas, nenhuma das quais é original: o texto é um tecido de citações, saídas dos mil focos da cultura. [...] o escritor não pode deixar de imitar um gesto sempre anterior, nunca original; o seu único poder é o de misturar as escritas, de as contrariar umas às outras, de modo a nunca se apoiar numa delas; se quisesse exprimir-se, pelo menos deveria saber que a «coisa» interior que tem a pretensão de «traduzir» não passa de um dicionário totalmente composto, cujas palavras só podem explicar-se através de outras palavras, e isso indefinidamente (BARTHES, 2004: 62).

É interessante perceber nesse enunciado que Barthes, ao falar sobre a morte do autor, alega que ao criar, o autor se apaga, cambiando a posse daquilo que produz pela potência da leitura, da interpretação. Em outras palavras, nesse manifesto, ele expressa que deve-se substituir a importância do papel do autor pela importância do papel do leitor. Sendo assim, um texto é feito de escritas múltiplas que entram em diálogo umas com as outras, e essa multiplicidade se manifesta no leitor (Barthes, 2004).

Essa desterritorialização do sacro altar do autor abre brechas para se perspectivar uma alternância entre as funções de autor e leitor, pois quebra com essa linearidade do esquema comunicativo (emissor > receptor). Desse modo, um texto passa a ser visto como intertexto no qual perde-se a referência do autor, porque são muitos os seus criadores. E o que ocorre quando o receptor é, ao mesmo tempo, um autor?

\section{Intertextualidade e tradução: possibilidades de coautoria}

Um texto existe porque é uma combinação de signos, um diálogo ad infinitum. Um texto jamais é raiz: é rizoma. 0 texto, em quaisquer de suas manifestações, é uma rede, nunca uma unidade isolada, porque é desprovida de centro ou ori- gem. Um trabalho artístico, nessas configurações, é sempre um texto aberto, sendo capaz de assimilar ou proferir novos signos.

Noutras palavras, é no receptor/leitor/público que a obra encontra seu clímax. Consoante a isso, "um objeto poético pode ser declarado aberto a outros objetos poéticos" (Greimas, c1972), ou seja, dotado de porosidade. Assim, pode-se dizer que um objeto artístico pode tanto absorver, como vazar conteúdo, e desse modo, apropriar-se de significações, ou doá-las. Há, nesses movimentos, um trânsito códico, um compartilhamento das unidades que compõem a obra. Retorna-se, desse modo, às relações dialógicas (Bakhtin, 2003), no momento em que se percebe como factual a chance de ocorrência desse trânsito de conteúdo, por assim dizer, de uma obra para outra. Desse modo,

Observa-se que a intertextualidade bakhtiniana, a não ser que a reduzam a um simples arrolamento de "influências literárias", não pode dispensar a mediação do universo semântico do sujeito produtor, onde se faz a recepção e a integração as "influências": dentro desse universo que se fazem as escoIhas das formas e dos conteúdos poéticos. 0 objeto poético se abre, finalmente, no próprio momento em que se manifesta na língua natural de sua escolha (GREIMAS, 1976: 29).

Mas e que isso tudo tem a ver com a questão da autoria? E mais, de que importa nesse contexto, saber se a obra se abre a interpretações para além daquelas idealizadas por seu criador? Ocorre que, nas condições em que: $\boldsymbol{a}$ ) um texto é, prioritariamente um intertexto; $\boldsymbol{b}$ ) seu potencial estético é aberto a significações externas, passível de complementação; e c) esse movimento autônomo da obra pode acontecer na interação com outra mente além de seu criador - tem-se, então, a possibilidade de uma reativação do potencial estético da obra, por meio de novas interpretações. 
Figura 2 - Pablo Picas so, Las Meninas, 1957 , $194 \times 260 \mathrm{~cm}$ (Museu Picasso). Fonte: www. pablopicasso.org

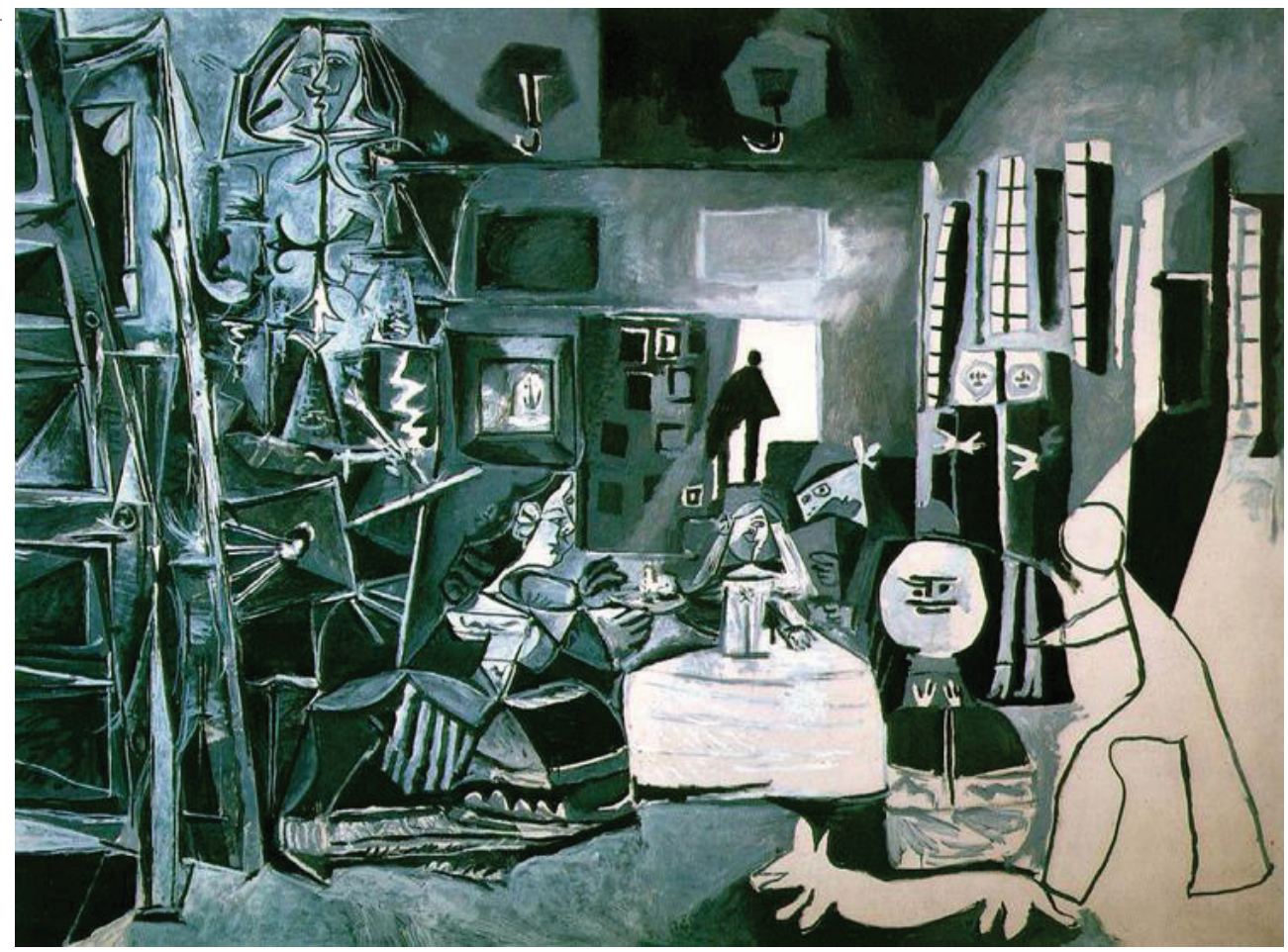

Então, pode-se dizer que "copiar" ou "roubar", nos moldes explicitados por Picasso, constituem práticas éticas dentro do estatuto da arte? É necessário, aqui, tomar certa cautela. Tentarse-á, desse modo, antes de induzir determinada perspectiva sobre a situação, refletir sobre ela.

Toma-se a "cópia" como primeiro âmbito para se pensar a respeito. Copiar uma obra, no sentido que Picasso fez com a obra de Velázquez (Figura 2), foi antes de tudo, uma maneira de frui-la. Nela, opera-se uma reflexão, um questionamento, como também um modo de ressignificação. Visto assim, é possível identificar a realização da transposição, para além da mimetização em si mesma: "Mesmo o processo pretendidamente mimético caracteriza-se pelo fato de algo tentar fazer-se igual a outro, mostrando-se como não-igual” (Plaza, 2003).

A postura do "roubo", dentro das artes visuais, está associada à citação, no sentido de "tomar algo" de um texto e transpo-lo para outro, como no ato de colar uma figura numa página de um álbum de colecionáveis. Essa atitude, a meu ver, foi exatamente aquela posta em prática por Braque em Fruit Dish and Glass (Figura 3). Assim, a invenção da colagem realizada nesse evento é considerada um divisor de águas para a história da arte no ocidente. Esses experimentos com a colagem refletiam uma nova subjetividade que dialogava diretamente com as mudanças culturais advindas da revolução industrial.

Em se tratando de arte contemporânea, o desenvolvimento das tecnologias digitais permitiu que se familiarizasse as operações de "recortar", "copiar" e "colar" (os atalhos Ctrl+X, Ctrl+C, CtrI+V no teclado dos computadores). Essa possibilidade de dominar um conteúdo, podendo modifica-lo à sua vontade, determinou uma nova postura generalizada em relação ao conteúdo das coisas, e isso se refletiu também na arte. 


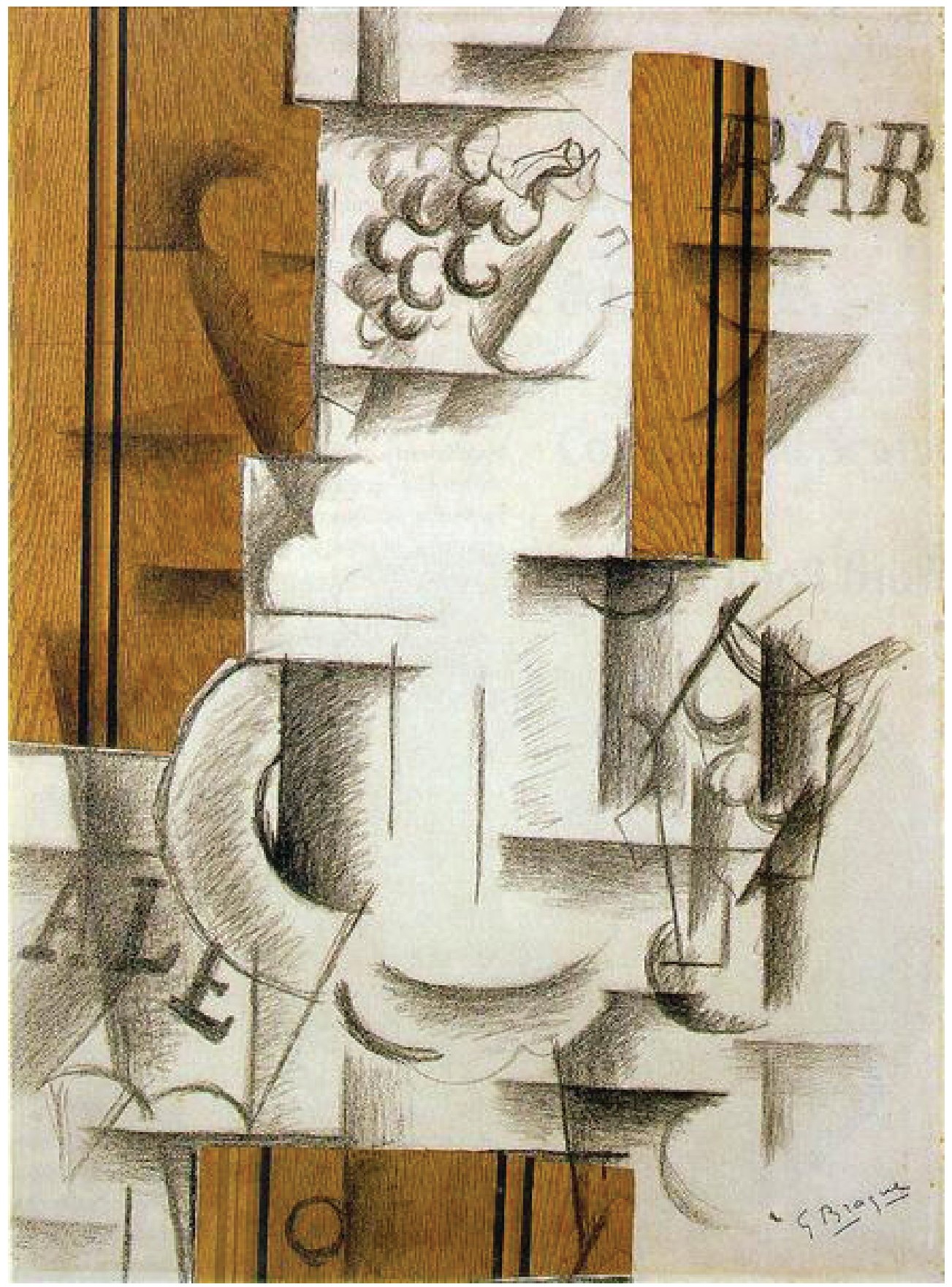

Figura 3 - Braque, Fruit Dish and Glass, 1912, 62,9x45,7cm (Museu do MET). Fonte: collectionapi.metmuseum.org 
Analogamente, as investigações praticadas por Picasso e Braque, que viriam a culminar na colagem, rompem com os cânones prescritos até então. Nesse caso, o uso de objetos do cotidiano na obra de arte (Braque), e a apropriação de imagens/textos alheios para a configuração de novos trabalhos artísticos (Picasso), são vitais para se entender a legitimidade desses artifícios na construção dessa nova perspectiva do estatuto da arte, que modifica-se muito rapidamente a partir do século XX.

Cabe a ressalva, neste ponto, que essas atitudes são completamente diferentes do que se entende por "réplica". Surpreendentemente, Bakhtin considera toda réplica um monólogo reduzido ao extremo. E que, coincidentemente, todo monólogo é réplica de um grande diálogo dentro de determinada esfera (Bakhtin, 2003). Assim, o monólogo é concebido como um discurso que não se dirige a ninguém e não pressupõe resposta, pois falta-Ihe significações uma vez que seu original foi o objeto projetado como obra - uma duplicação, destituída de quaisquer renovações.

O emprego do termo "réplica", geralmente, está vinculado a situações muito específicas, nas quais tentou-se, por quaisquer motivos, substituir os textos originais. American Gothic (1930), de Grant Wood, ou a Mona Lisa (15031507), de Leonardo DaVinci, ou The Great Wave of Kanagawa (1829-1832), de Katsushika Hokusai são consideradas as obras mais ressignificadas da história, ${ }^{2}$ e assim mesmo jamais foram suplantadas por uma produção posterior. É importante, nesse sentido, perceber que uma obra é carregada de aura (no sentido benjaminiano), e que tal qualidade demanda muito mais do que

2 Cf. SHEEN, By Annabel. 10 of the most parodied artworks of all time. 2017. Disponível em: <https://www.royalacademy. org.uk/article/america-after-the-fall-10-most-parodied-artworks>. Acesso em: 14 abr. 2017. uma tentativa de reprodução para substitui-la. Eis a prova da importância da arte na constituição do Zeitgeist.

\section{Tradução intersemiótica na arte}

Tomando como pressupostos a semiótica peirciana e a tipificação de tradução de Jakobson, Julio Plaza desenvolve estudos sobre o pensamento como tradução. Para o autor (Plaza, 2003), todo pensamento é transmutação de signo em signo. Ao pensar, traduz-se tudo o que está em nossa consciência, seja imagens, sentimentos ou ideias em outras representações também sígnicas. Assim, entende-se que todo pensamento seria a tradução de outro pensamento, pois para todo pensamento requer, primeiramente, ter havido outro pensamento para o qual ele funciona como interpretante.

Sendo o signo a única realidade capaz de transitar entre o que se denomina mundo interior e exterior, o seu trânsito já exerce função dialógica, pois foi internalizado no pensamento do sujeito que irá extrojeta-lo por meio da linguagem. No caso do artista, esse enunciado é materializado na obra. Ou seja, existindo como um texto denotativo, a obra possui uma probabilidade factível de tradução. Todavia, essa tradução torna-se possível se operada como transposição criativa, quer dizer, quando se transpõe de um sistema sígnico para outro.

Dito isso, distinguem-se três maneiras de interpretação de um signo, sendo a tradução entre diferentes sistemas códicos, ou intersemiótica, a que interessa a presente pesquisa. Segundo o autor (Jakobson, 2008), a "tradução intersemiótica ou transmutação consiste na interpretação dos signos verbais por meio de sistemas de signos não-verbais". Ou seja, quando traduz-se um texto falado ou escrito, para um texto visual, por exemplo. O referimento à possibilidade de coautoria, nesse sentido, está para a 


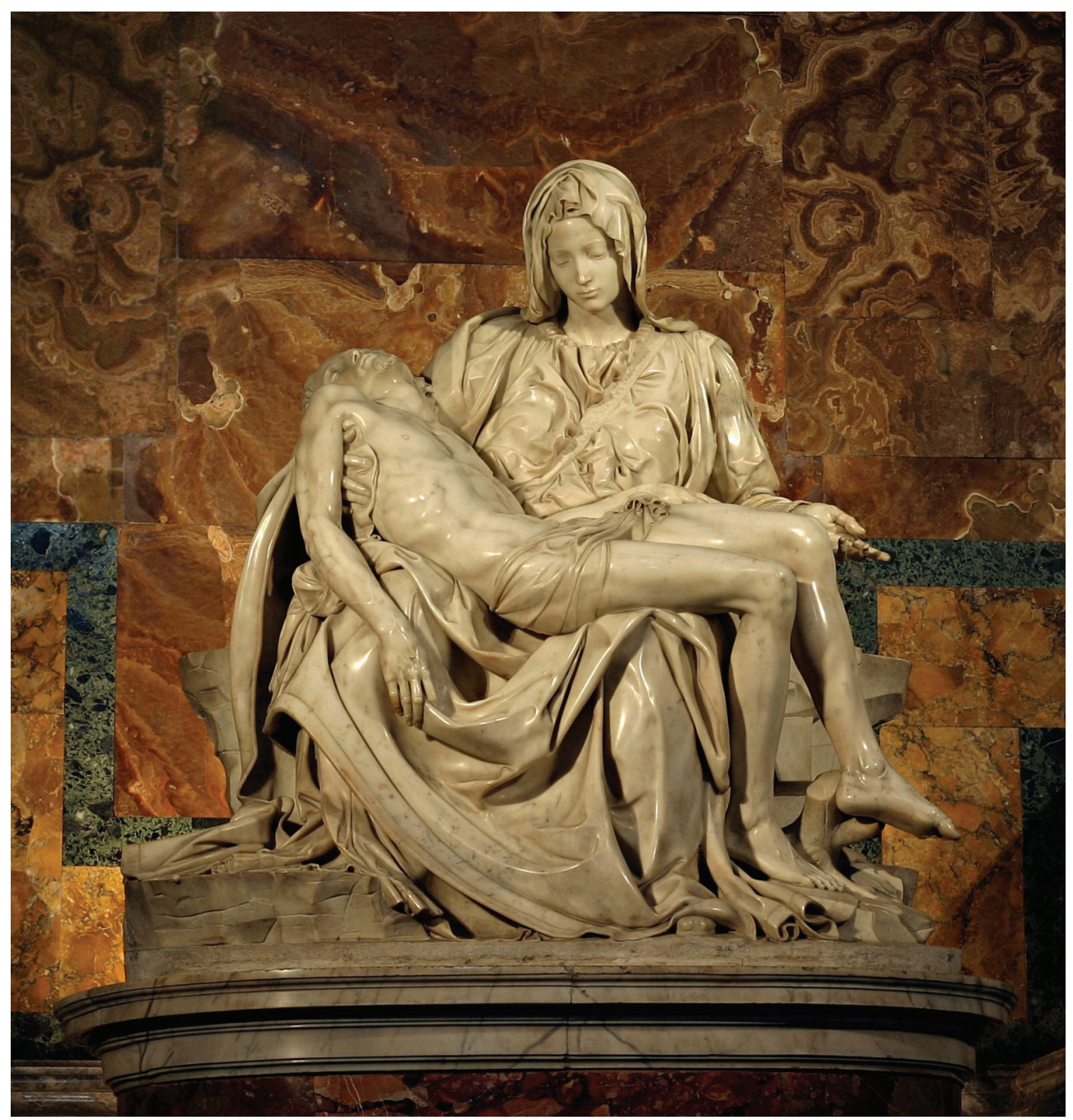

Figura 4 - Michelangelo, Pietà, 1499, 174x195cm (Basílica de São Pedro)

concessão em se poder realizar essas traduções e gerar novos objetos poéticos. Assumir a postura de coautor, desse modo, é novamente pôr em destaque o papel da fruição em detrimento do espetáculo da individuação autoral. Enfim, uma obra, considerada sincronicamente como um intertexto polifônico e uma tradução, apresentaria sempre vestígios de seus originais nela. Vejamos na prática como isso funciona.

A Pietà de Michelangelo (1499) foi uma obra encomendada ao artista renascentista no ano de 1498. Essa obra é a única obra nomeadamente assinada por Michelangelo, visto que todas as outras que se tem conhecimento são atribuídas à sua autoria com incerteza, ou manifestas em coautoria com sob supervisão de outrem. Nela (Figura 6), vê-se o corpo de Jesus no colo de Maria, após sua crucificação.

Na visão de Hölderlin (Plaza, Id.), a tradução "é emenda, externalização, extrojeção, mas é também correção." Essa correção se daria pelo fato de que a visão que o tradutor tem do texto ori- 
Figura 5-Bill Viola, Mary, 2016, 155,4×237,$2 \mathrm{~cm}$ (Catedral de St. Paul). Fonte: billciolaatstpauls.com

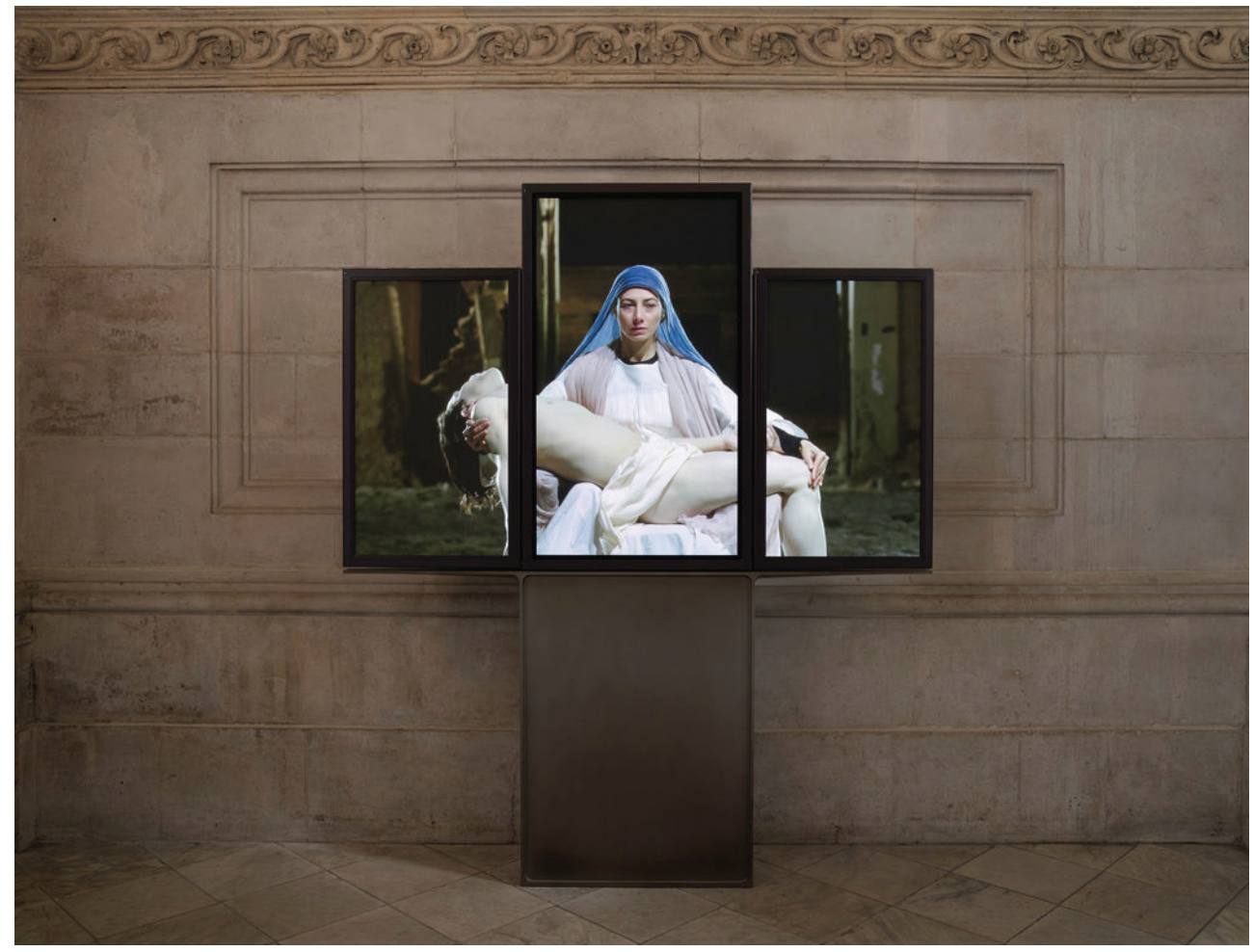

ginal é diacrônica. Assim, "o tempo e a evolução da sensibilidade deram ao seu eco um poder de preenchimento. A correção feita pelo tradutor está virtual no original, mas apenas ele pode materializa-la" (Plaza, Ibid.). De certo modo, pode-se dizer que uma tradução não é, de todo, transparente. Ela não oculta nem suplanta seu texto anterior, porém é perceptível, em muitos casos, o desejo do artista tradutor em superar o seu original. Cabe lembrar que a leitura, a tradução, a crítica e a análise são operações simultâneas, sintetizadas na operação tradutora de que se fala.

Diferentemente do que se viu na imagem anterior, em Mary (Figura 7), no lugar de uma escultura, vê-se um objeto escultural constituído por três telas de plasma acopladas a uma quarta estrutura, formando uma cruz na qual é transmitida um vídeo. O tríptico mostra a imagem de uma mulher que carrega o corpo desfalecido de um homem em seus braços, cena muito conhecida das religiões cristãs. Ao comparar as imagens dessas duas obras, pode-se dizer que Viola apresenta a materialização do conceito de tradução intersemiótica, uma vez que ele transpõe os signos presentes na escultura renascentista para a tecnologia digital do vídeo.

Ademais, a tradução mantém uma relação intima com seu original, ao qual deve sua existência, porém é nela que expande e renova seu sentido (Plaza, Id.). Assim, a obra original e sua tradução complementam-se mutuamente, pois tanto a tradução pode clarificar significados possíveis da obra original, como esta pode potencializar os sentidos de sua tradução. Para o autor (Plaza, Ibid.), o original está determinado pelas condições de produção que nele estão inscritas, a saber, de seu contexto. O signo, des- 
sa maneira, indica sempre algo que está fora dele, pois todo signo está marcado pelas condições de sua temporalidade, de sua feitura. Portanto, a leitura do original exige também uma leitura das condições de sua produção.

\section{A câmera como transdutor}

Transpondo essa teoria para o campo artístico, torna-se evidente que uma obra, compreendida como um signo estético, é simultaneamente um intertexto e uma tradução. Isso porque nenhum artista é independente de predecessores e modelos (Plaza, 1987). Na realidade, a história é parte integrante da realidade humana e, ocupar-se com o seu passado é também ocupar-se com o seu presente.

Nesse sentido, Viola pronuncia que "o artista do século vinte não necessariamente é alguém que desenha bem, mas alguém que pensa bem". ${ }^{3}$ Assim, ele estaria assumindo simultaneamente que faz uso de artefatos existentes para realizar sua arte; e que a produção assim concretizada (no sentido intertextual ou tradutório) também possui um teor de ressignificação da obra anterior.

Há décadas, o artista explora as camadas mais misteriosas e profundas da vida, usando tecnologia de ponta disponível ano após ano, para ressonar temas arquetípicos da condição humana. Ocorre também, na sua videoarte, que além do artifício da intertextualidade, Viola transcende a materialidade do suporte. Fala-se, assim, da sua escolha por designar o meio do vídeo para reapresentar uma imagem criada em outro meio, operando assim, sua tradução. Além disso, sua prática de artista/tradutor revoga a postura da autoria, porque um autor apresenta um significado fixo e uma explicação,

3 Bill Viola, Reasons for Knocking at an Empty House (Cambridge: MIT Press, 1995), p. 64. Tradução livre. quando, ao contrário, ele fornece um espaço de revisitação interminável, visando a infinita formação de significados e leituras que nunca são definitivas ou singulares na descrição das verdades da arte.

Bill Viola, nesse sentido, tem sido um exímio tradutor: grande parte de suas obras são traduções intersemióticas de pinturas, esculturas, poemas, afrescos e outras produções de meios analógicos transpostos para o vídeo digital. Nesse contexto, a câmera e o todo aparato tecnológico que o possibilita montar os vídeos exercem o papel de transdutores. Um transdutor é um "elemento cibernético que governa e converte uma forma de energia em outra" (Arnold \& White, 1963), cuja tendência é conservar a carga energética do signo original, ou seja, é de manter a invariância na equivalência (Plaza, 2003).

\section{Considerações finais}

Nota-se, desde a segunda revolução industrial, e mais enfaticamente ainda na atualidade, que esses processos de tradução e transposição são largamente utilizados. Seja nas artes visuais, seja na literatura ou publicidade, ou ainda diversos outros meios nos quais se utiliza a linguagem como forma de comunicação, há pois, processos de transposição intrínsecos ao discurso enunciado.

Se tomarmos como regra a máxima bakhtiniana de que todo texto é um cruzamento de enunciados anteriores ao discurso presente, seria possível afirmar que, de fato, não há autor visto como o criador de um "original". Isso porque a invenção referida seria um compilado de referências apresentada de modo singular, e essa singularidade não outorga ao seu criador o título de proprietário do todo que esse produto representa, mas sim um tradutor de ideias que as configura através da linguagem. 
Mesmo ao negar-se a origem de determinada produção artística, é genuíno dizer que toda criação tem origem na arte precedente, pois nada é produzido no vazio. Entretanto, na tradução essa realidade é acentuada, pois esse é o lugar da combinação. São nos desvios da repetição que se encontram os traços de singularidade que permitem renovar a carga aurática das obras, ou simplesmente carregá-las de algo que Ihes carecia na configuração original.

Nesse sentido, pode-se pensar nas obras como sobreposições de diferentes temporalidades, compondo a união entre passado e presente numa tradução de tempos e conteúdo semântico que vêm a se completar. A obra, anacrônica, é uma expressão do fora espaço-temporal. Isso porque o contexto em que é criada, dá-Ihe toda uma configuração semântica, mas esse limitador de espaço e de tempo nem sempre lhe atribuem as mais potentes significações.

Lembremo-nos também, da sensível expressão bakhtiniana sobre esse aparato intertextual que lhe foi tão caro: o texto é a expressão de uma consciência que reflete algo. Logo, ao olhar para uma obra e refletir acerca de sua potência é um exercício de troca, e não somente de análise. Pôr-se frente a um artefato e refletir sobre ele, é assim, debruçar-se nele e enxergar seu reflexo sobre a obra. É como olhar para a imagem de seu reflexo num espelho de água parada, com o adicional de que esta água, límpida e transparente, permite se ver o que há debaixo dela. É um exercício no qual pensa-se em si (no que se pode dizer sobre a obra) e no outro (na obra em si e naquele quem a fez). Encontrar, nessa prática, o que há entre o seu reflexo e o objeto do fundo da água, é o desafio que se propõe. Assim como o artista Bill Viola, que usa a poética ao se colocar no entre-meio, nessa virtualidade da tradução.

\section{Referências}

ARNOLD, Pauline; WHITE, Percival. A era da automação. Rio de janeiro: Lidador, 1963.

BAKHTIN, M. M. Estética da criação verbal. 6. ed. São Paulo: Martins Fontes, 2003.

FATORELLI, Antonio. Além da superfície, de Cleverson Oliveira. Vazantes, Fortaleza, v. 1, n. 1 , p.118-126, 2017.

GREIMAS, Algirdas Julien (Org.). Ensaios de semiótica poética: com estudo sobre Apollinaire, Bataille, Baudelaire, Hugo, Jarry, Mallarme, Michaux, Nerval, Rimbaud, Roubaud. São Paulo, SP: Cultrix: USP, 1976, c1972.

HINKEL, Irina A. What is contemporary art? 2016. 73 f. Dissertação (Mestrado) - Curso de Arts, Purdue University, West Lafayette, 2016. JAKOBSON, Roman. Linguística e comunicação. 21. ed. São Paulo, SP: Cultrix, 2008.

PLAZA, Julio. Tradução intersemiótica. 2. ed. São Paulo: Perspectiva, 2003. 